\title{
Arduino Based Temperature And Humidity Monitoring Control System for Day Old Chicken (DOC) Cage
}

\author{
Akbar Sujiwa \\ Department of Electrical Engineering \\ University of PGRI Adi Buana Surabaya \\ akbarsujiwa@unipasby.ac.id
}

\author{
Muhammad Ubaydillah \\ Department of Electrical Engineering \\ University of PGRI Adi Buana Surabaya \\ muhammadubaydillah05@gmail.com
}

\begin{abstract}
In general, conventional cattle sheds using manual systems and human labor are very reliable, in the conventional process of heating cattle sheds, we still encounter many using oil stoves and lamps as a DOC heating process. However, the use of oil stoves and lamps is dangerous and unstable. In addition to the DOC heater using the lamp, there is also a DOC heater using an element heater.

The advantage of using a heating element, the temperature can be adjusted according to your needs. The use of heating elements in chicken coops is still rarely used. Therefore, a research was conducted on the manufacture of a temperature and humidity monitoring control system based on Arduino Mega in the Day Old Chicken (doc) cage.

DHT 11 sensor accuracy level calibrated with room temperature measuring instrument Taffware HTC-2 is known DHT 11 sensor has an accuracy in reading temperature that is $96 \%$ with a dispute of $3.8 \%$. And the accuracy in reading humidity is $89.8 \%$ with a difference of $11 \%$.
\end{abstract}

Keywords - Day Old Chicken (DOC), Arduino, Heating Element, sensor DHT 11.

\section{INTRODUCTION}

Day Old Chicken is a chicken that has an age or age below 10 days to 14 days, the maximum age is calculated from the first day the chicken hatches. . In DOC care, breeders experience a loss if in the treatment process there is an error, for example the temperature of the cage, in the process of treating the cage temperature used for DOC must match the conditions of the cage. If the maintenance is lacking, the DOC will die, and the farmer will experience a big loss.

Chickens will grow optimally if kept in a comfortable cage. Low temperatures cause chickens to flock and be lazy to do activities, while high temperatures cause chickens to increase drinking water consumption and reduce feed consumption. The need for environmental temperature can be met by providing brood stock cages using a type of heating device capable of producing heat directly or indirectly. (Dede Risnajati: 2011)

Research conducted by Muh Fuad Mansyur (2019) with the title Design to Build an Automatic Control System for Temperature and Humidity Regulating Broiler Chicken Cages Using Arduino. Broiler breeders still use manual methods to maintain the optimal temperature of the house. This routine causes a problem, namely the farmer's forgetfulness in maintaining the temperature and humidity in his livestock pen. However, the drawback of this research is the lack of a maximum in preparing better tools and components.

\section{METHODS}

At this stage, the components and materials used are selected based on the literatures obtained. This stage is also intended to obtain data in research.

This stage is the stage of making the design and designing components of the system. In general, the design of our day old chicken (DOC) cage concept is as shown below.

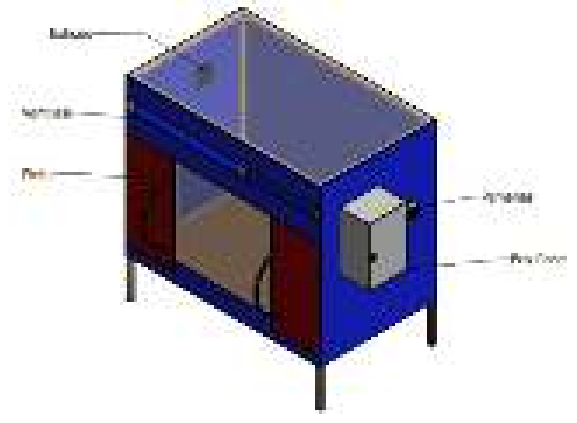

Fig. 1 Design drawing of the cage 
There is a process in conducting this research, namely making the cage, assembling the components and coding the system. To build this system using several components, including the following:

\section{a. Arduino Mega}

Arduino Mega is generally made using the ATMega 2560 microcontroller type. As the name implies, this Arduino is equipped with an ATMega2560 processor which has 54 digital I / O pins (of which 15 pins can be used as PWM output), 16 analog input pins, 4 UART pins, $2 \times 3$ pins ICSP (for programming Arduino with other software), and a computer USB cable which is also used as a voltage source.

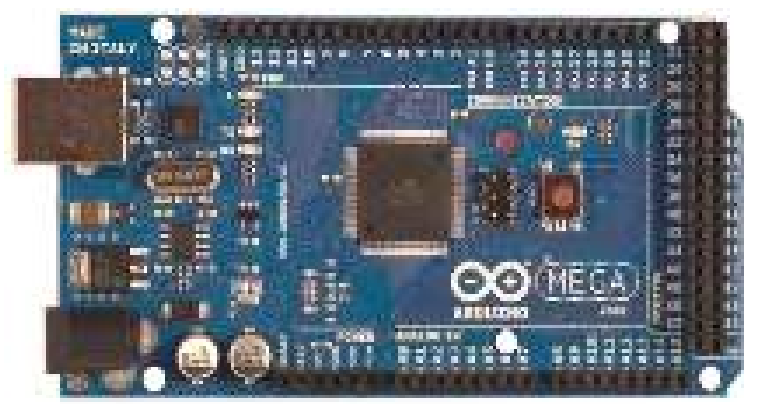

Fig. 2 Arduino Mega image

\section{b. Sensor DHT11}

The DHT11 sensor is a sensor module that functions to measure two environmental parameters at once, namely temperature and humidity

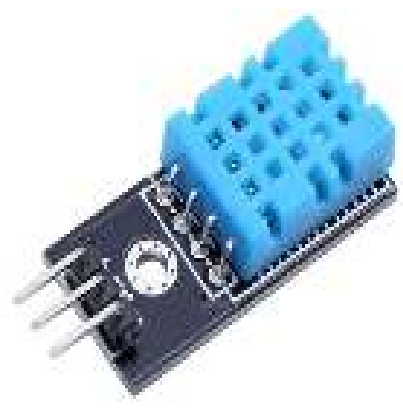

Fig. 3. DHT11 sensor image

\section{c. Heating Element}

The heating element is a means of converting electric power into heat power or this component functions as a heat generator. The working principle is the same as the needs of household appliances such as ovens and irons. The heating element requirements include:

1. Must be durable at the desired temperature

2. Mechanical properties must be strong at the desired temperature.

3. The coefficient of expansion must be small, so that the change in shape at the desired temperature is not too large.

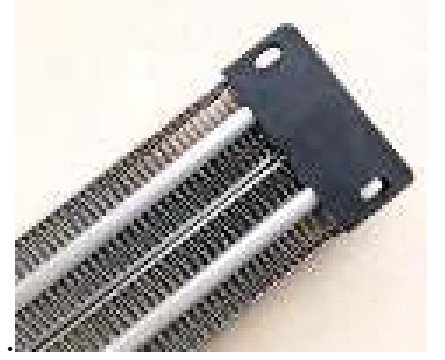

Fig. 4. Heating element image

\section{d. Relay}

Relay is a mechanical switch that is controlled or electromagnetically controlled. In principle, the relay is a switch lever with a wire wound on an iron rod (selenoid). Relays in the electrical world function to cut or flow controlled electric current by providing a supply voltage to the coil. There are two types of relays based on the supply voltage on the coil, namely AC and DC.

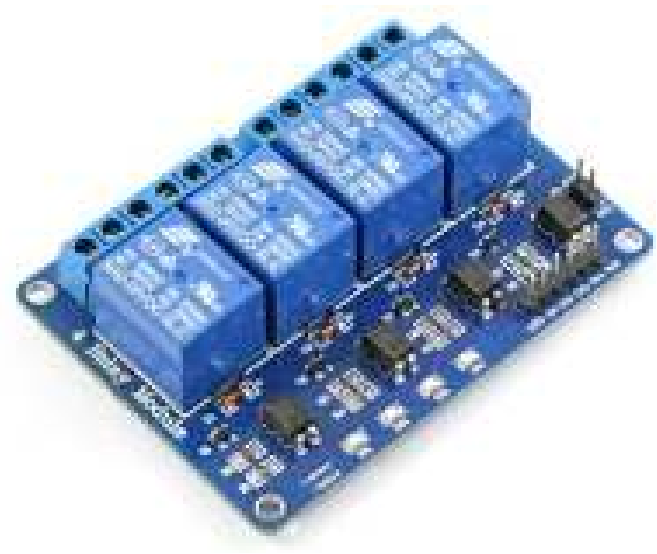

Fig. 5 Relay image

\section{e. Control System}

In this study using an on / off control. The on / off control is a controller whose action only has two specific values, namely: 


$$
\begin{aligned}
u(t) & =U_{1} \text { untuk } e(t)>0 \\
& =U_{2} \text { untuk } e(t)<0
\end{aligned}
$$

Diagram blok kontroler on/off adalah sebagai berikut :

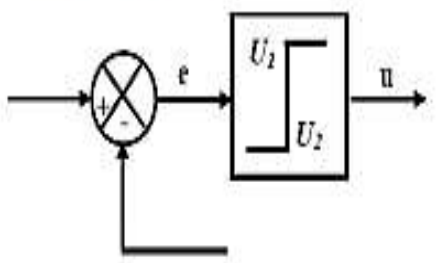

Basic on / off control is applied to the control system for the physical quantity of heating systems, heating systems, incubators for babies, etc.

In the on / off control provides a delay time to improve the performance of the control system. In the on / off control there are 2 important aspects, namely:

1. The isolation frequency response which affects the aquatic

2. The amplitude of the response oscillation that affects the accuracy of the control and the amount of energy losses in the response of the overall control system..

The on / off controller using this controller performance hysteresis is as follows:

1. If the room temperature is below the lowest set-point then the heating system will be $\mathrm{ON}$

2. If the room temperature rises above the lowest set-point but is still below the top set-point, the heating system will remain ON.

3 . If the room temperature is above the top setpoint then the heating system will be OFF.

4. If the room temperature drops below the top set-point but is still above the lowest setpoint, the heating system will be

\section{RESULT AND DISCUSSION}

From the test results obtained some data. The data obtained include the accuracy of the DHT 11 sensor which is calibrated with the Taffware HTC-2 room temperature measuring instrument and the state of the enclosure with the operation of the system. This test is done to find out how the system is performing.

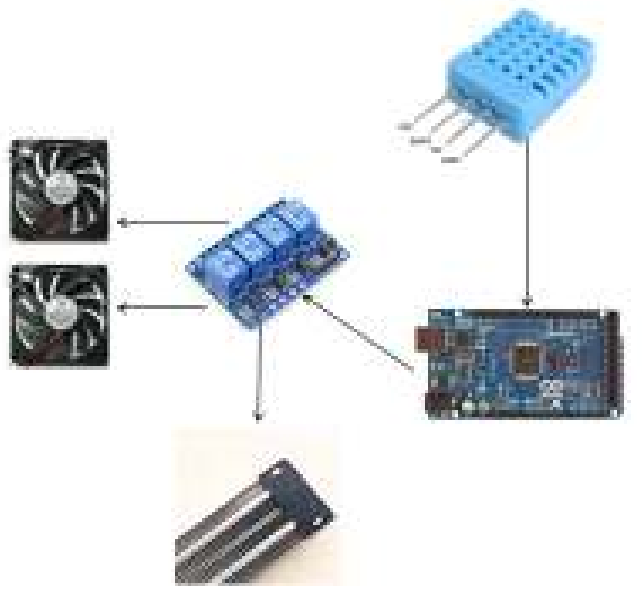

Fig. 6 System circuit drawing

\section{a. Testing the accuracy of the DHT11 sensor}

Table 1. Testing the accuracy of the DHT11

\begin{tabular}{|c|c|c|c|c|c|}
\hline \multirow[b]{2}{*}{ No. } & \multirow{2}{*}{ 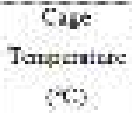 } & \multicolumn{2}{|c|}{ Torveratue Rejeirss (D) } & \multirow[b]{2}{*}{ IEAfanes: 19} & \\
\hline & & $\mathrm{FIC-2}$ & DatII & & \\
\hline 1 & 32 & 32 & $x$ & 0 & \\
\hline 1 & S1 & 51 & 87 & 0 & \\
\hline 3 & $\$ 1$ & $\$ 1$ & $\$ 1$ & 0 & \\
\hline+ & 3 & 34 & 38 & 4 & \\
\hline 5 & 37 & 37 & 39 & 2 & \\
\hline 6 & 37 & 37 & 40 & 3 & \\
\hline 7 & $3 a$ & $\otimes$ & $\Delta$ & 2 & \\
\hline 8 & Sis & SII & at & 1 & \\
\hline 7 & $\bar{x}$ & $\bar{M}$ & क1 & 9 & \\
\hline iii & 8 & 78 & Ct & 2 & \\
\hline ]t & क) & 5 & 41 & 1 & \\
\hline$T$ & क) & 5 & 4 & 1 & \\
\hline
\end{tabular}
sensor

Table 2 . Cage humidity reading accuracy test

\begin{tabular}{|c|c|c|c|c|}
\hline \multirow[b]{2}{*}{ So } & \multirow{2}{*}{$\begin{array}{c}\text { B.H Cus } \\
\text { Humidity } \\
\text { csij }\end{array}$} & \multicolumn{2}{|c|}{ 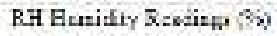 } & \multirow[b]{2}{*}{ Difienaze Pos } \\
\hline & & $\operatorname{ETC}-2$ & DETL1 & \\
\hline 7 & ब्व & 94 & is & 1 \\
\hline 2 & का & का & S6 & 5 \\
\hline 1 & $\bar{m}$ & ส7 & Fi & a \\
\hline 1 & 72 & 77 & कर & 30 \\
\hline 12 & 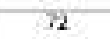 & $\gamma$ & 50 & 8 \\
\hline 5 & 6 & 6 & $n$ & 21 \\
\hline 7 & 62 & 62 & 74 & 22 \\
\hline 3 & $\infty$ & $\infty$ & 33 & 13 \\
\hline 8 & SA & 9 & $\sqrt{7}$ & 73 \\
\hline 11 & 24 & $\bar{k}$ & m & 28 \\
\hline $1 !$ & 5 & 5 & B & - \\
\hline 12 & 57 & 52 & $\$ 2$ & 7 \\
\hline
\end{tabular}
table

After conducting an experiment to determine the accuracy of the sensor and the performance of Arduino Mega in running the system, it has got 
the desired results. The sensor detects the temperature in the room (chicken coop) and Arduino is able to run the program properly. Although there are still some that still need improvement.

According to the data that has been obtained when conducting system testing, namely the dispute over the reading of the temperature sensor calibrated with the Taffware HTC-2 room temperature gauge, it is known that the DHT 11 sensor has an accuracy in reading temperature, namely $96 \%$ with a dispute of $3.8 \%$. And the accuracy in reading humidity is $89.8 \%$ with a difference of $11 \%$.

The data obtained at the time of research on the behavior of chicks, namely:

1. When the observation is made at a house temperature of less than $26^{\circ}$, it is known that the behavior of the chickens is seen to be more clustered and cold.

2. When observing the house temperature in the range of $26^{\circ} \mathrm{C}-32^{\circ} \mathrm{C}$, it is known that the behavior of the chickens is seen to be more enthusiastic

3. When observing the temperature in the cage more than $32^{\circ} \mathrm{C}$, it can be seen that the chicken's behavior is always opening its mouth and tends to drink more

\section{CONCLUSION}

From the testing of the tools that have been carried out, several conclusions can be taken including:

1. Arduino Mega is able to control the system in a tool to control the temperature in the cage and display the results of sensor readings in the cage to the monitor and adjust the performance of elements and fans.

2. The level of accuracy of the DHT 11 sensor calibrated with the room temperature measuring instrument Taffware HTC-2 is known to have DHT 11 sensor accuracy in reading temperatures, namely $96 \%$ with a dispute of $3.8 \%$. And the accuracy in reading humidity is $89.8 \%$ with a difference of $11 \%$.

3. From several temperature observations, it can be seen that chickens look more comfortable in the temperature range of $26^{\circ} \mathrm{C}-32^{\circ} \mathrm{C}$. All devices connected to the system are able to work properly according to the program that the user has provided through Arduino.

4. All devices connected to the system are able to work properly according to the program the user has provided via Arduino.

\section{REFERENCES}

[1] Mansyur, Fuad Muh.2019. Rancangan Bangun Sistem Kontrol Otomatis Pengatur Suhu dan Kelembapan Kandang Ayam Broiler Menggunakan Arduino. Jurnal Of Computer and Information System (J-CIS). Sulawesi Barat. Universitas Sulawesi Barat.

[2] Junaidi, Prabowo Dwi Yuliyan.2018. Project Sistem Kendali Elektronik Berbasis Arduino.

[3] Bandar Lampung:CV Anugrah Utama Raharja.

[4] Syam, Rafiuddin.2013. Dasar dasar Teknik Sensor. Makassar:Fakultas Teknik Universitas Hasanuddin.

[5] Sujiwa, Akbar, and Sagita Rochman. "Pengembangan Sistem Kontrol Serta Monitoring Suhu dan Volume Air Berbasis Web Pada Perangkat Desalinasi Air Laut." SNHRP (2019): 1-9.

[6] Rochman, Sagita, and Bagus Ilham Yunianto. "PROTOTYPE AUTOMATIC LIGHTS CONTROL SYSTEM IN THE MOSQUE AREA BASED ON ARDUINO NANO." BEST: Journal of Applied Electrical, Science, \& Technology 1.1 (2019): 32-35.

[7] Rochman, Sagita, and M. Nushron Ali Mukhtar. "CLASSIFICATION OF THE QUALITY OF HONEY USING THE SPECTROFOTOMETER AND MACHINE LEARNING SYSTEM BASED ON SINGLE BOARD COMPUTER." Tibuana 2.01 (2019): 45-49. 